\title{
A Review: The Emerging Nutraceutical Potential of Pumpkin Seeds
}

\author{
Beni Lestari, Edy Meiyanto* \\ Cancer Chemoprevention Research Center, Faculty of Pharmacy, Universitas Gadjah Mada, Yogyakarta, Indonesia
}

\begin{abstract}
The pumpkin belongs to the family of Cucurbitaceae, is a well-known edible plant that has been frequently used as functional food or herbal medicine. Pumpkins contain rich unsaturated fatty acids, phytoestrogens and vitamins $E$ in their seeds that have potential pharmaceutical, nutraceutical, and cosmeceutical properties. Information regarding their nutritional components and therapeutic properties of pumpkin seeds has expanded dynamically in the recent years and this review focus on the three main components of pumpkin seeds that described before. Several types of unsaturated fatty acids are the dominant component in pumpkin seeds which can play a role in the disease prevention and promote health. Pumpkin seeds also contain the important phytoestrogen compounds, i.e., secoisolariciresinol and lariciresinol that have estrogenic-like effect such as preventing hyperlipidemia and osteoporosis for menopausal women. Phytoestrogens in pumpkin seeds also could be related to a reduced hormone-dependent tumor. Pumpkin seeds are rich in vitamin $\mathrm{E}$ contents as an emerging free radical scavenger, anti-aging and antioxidant such as $\alpha$-tocopherol and $\gamma$-tocopherol. Findings of these studies prove that patents field for the innovation product of pumpkin seeds holds promise for the future along with their immense nutraceutical properties.
\end{abstract}

Keywords : pumpkin seeds, estrogenic, anticancer, antioxidant, nutraceutical

\section{INTRODUCTION}

Pumpkin (Cucurbita sp.) is a fruit vegetable, native to the Western Hemisphere and easily cultivated in Tropical Asia countries such as Indonesia, Malaysia, and Philippines (Tindall, 1983). There are many varieties of pumpkin such as Cucurbita maxima, Cucurbita pepo, Cucurbita moschata, Cucurbita ficifolia, and Cucurbita turbaniformis in which Cucurbita moschata exhibits the widest variation in Indonesia, showed in Fig. 1 (Gemrot, et al., 2006). Although the pumpkin itself has various benefits, the pumpkin seeds have been the focus of interest in the last few years in the field of diet and disease research due to the emerging various active components.

Research on pumpkin increases progressively during the last decade, especially focusing on its health benefits. Pubmed recorded more than 200 papers within $2007-2018$ of pumpkin and its

Submitted: June 11, 2018

Revised: June 30, 2018

Accepted: June 30, 2018

*Corresponding author: meiyan_e@ugm.ac.id 


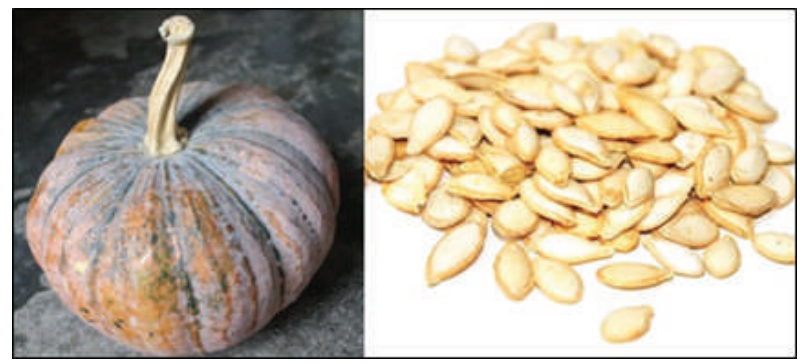

Figure 1. The pumpkin fruit (left) and its seeds (right) commonly cultivated in Indonesia known as Cucurbita moschata.

seeds covering on the field of chemistry, biology, pharmacology, and health. Among those of the researches, pumpkin seeds become the focus of interest due to its complexity of the chemical ingredient as well as the health benefits. Pumpkin seeds are highly nutritional and rich nutraceutical components such as unsaturated fatty acids especially palmitic acid, stearic acid, oleic acid and linoleic acid (Stevenson, et al., 2007). Those essential fatty acids are belonging to the $\omega-6$ and $\omega-3$ family which exert amazing nutritional functions and play important role in many metabolic pathways (Miura, 2013). Phytoestrogen supplementation with pumpkin seeds extract has been reported to increase uterine weight, mammary gland, bone density, and prevent hyperlipidemia, the indication of estrogen-like activities in ovariectomized female Sprague dawley rats (Gossell-Williams, et al., 2008). Pumpkin seeds oil contains rich vitamin $E$ such as $\alpha$-tocopherol and $\gamma$-tocopherol that exhibited positive health effects (Rabrenovic, et al., 2014).

The researchers have so far focused particularly on the three major components of fatty acids, phytoestrogens, and tocopherol in pumpkin seeds oil because they gained attention due to the several health benefits such as antioxidant, anti-inflammation, antidiabetic, anticancer, anti-cardiovascular, antihyperlipidemia, and estrogenic-like effect (Table 2 ). Thus, in this review, we explained more detail about the three major bioactive compounds of pumpkin seeds such as fatty acids, phytoestrogens, and tocopherols as well as to highlight the immense potential effects in the form of roasted, oil and/or extract of pumpkin seeds as the excellent nutraceuticals in the future.

\section{PHYSICOCHEMICAL COMPOSITIONS OF PUMPKIN SEEDS}

The different species of pumpkin seeds exerts the different components and biological activities (Caili, et al., 2006). Many researchers studied the bioactive compositions of pumpkin seeds oil that grown in the different areas of the world. Due to the differences among the species and/or varieties of Cucurbita spp., the yield of fatty acids, sterols or phytoestrogens and tocopherols was quite similar to those of each other and belong to the three major components of pumpkin seeds that have been focused by many studies. However, the minor components of pumpkin seeds such as protein, mineral, terpenic alcohol, and fiber also could not be ignored, because they have played role in the synergistic positive effects of pumpkin seeds ( $\mathrm{Fu}$, et al., 2006). Some technologies are applied to isolate the higher yield of oil from crude pumpkin seeds. Although several studies reported that crude pumpkin seeds extract itself exhibited the broad-spectrum pharmacological effects through in vitro, in vivo and human trial.

Cucurbita pepo $\mathrm{L}$. is the most popular pumpkin species to be a focus of interest of researches in the world. Recent studies have shown that Cucurbita pepo species is rich in polyunsaturated fatty acids such as palmitic acid, stearic acid, oleic acid and linoleic acid, vitamin E like $\alpha$-tocopherols, $\gamma$-tocopherols and carotenoid, phytoestrogens and phytosterols such as daidzein, genistein, secoisolariciresinol, and the trace components. Among those of total percentage of ingredients in pumpkin seeds, unsaturated fatty acids showed the hugest components ranging up to $80 \%$. This value is relatively higher than those reported for peanut seeds oil and soybean seeds oil (Cerny, et al., 1971; Sanders, 1980). The nutrient component in pumpkin seeds is presented in Table 1. 
(a) Fatty acids

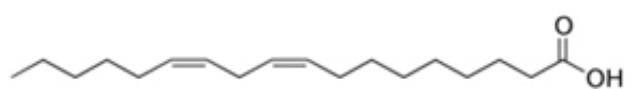

(i) Linoleic acids

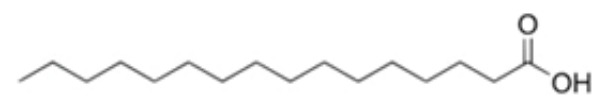

(iii) Palmitic acids

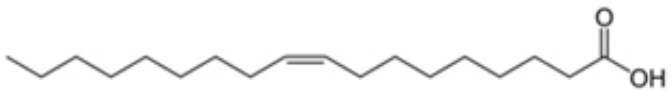

(ii) Oleic acids

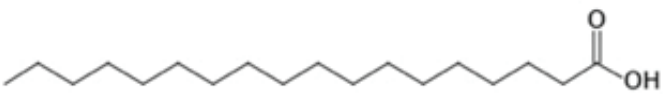

(iv) Stearic acids

(b) Phytoestrogens<smiles>COc1cc(C[C@@H](CO)[C@H](CO)Cc2ccc(O)c(OC)c2)ccc1O</smiles>

(i) Secoisolariciresinol<smiles>COc1cc(CC2COC(c3ccc(O)c(OC)c3)C2CO)ccc1O</smiles>

(ii) Lariciresinol

(c) Vitamins

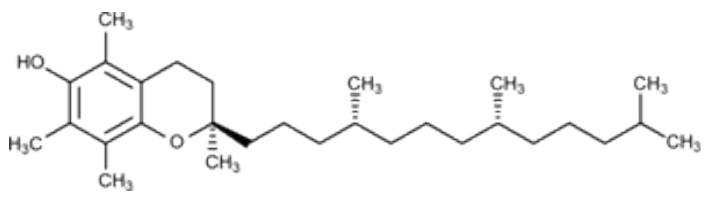

(i) $\alpha$-tocopherol

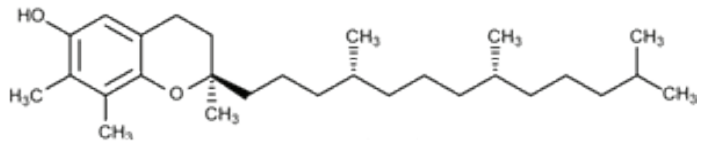

(ii) $\gamma$-tocopherol

Figure 2. Structures of the major compounds isolated from pumpkin seeds.

The second popular pumpkin species is Cucurbita maxima which is cultivated in many areas in the world. Rezig, et al. (2012) determined the chemical components of pumpkin seeds and the oil properties from the seeds of Cucurbita maxima from Tunisia. They reported that the abundant composition was fatty acids and tocopherol. Another researcher also studied nutritional component of different varieties of Curcubita maxima L. var. Berrettina and found that the major fatty acids were oleic acids and the highest components was sterols (Montesano, et al., 2018). Due to the different components among the varieties of Cucurbita grown in the different areas of the world, all studies agreed that pumpkin seeds are a good source of many nutrients. 
Indonesian Journal of Cancer Chemoprevention, June 2018

Table 1. Nutritional components of pumpkin seeds.

\begin{tabular}{|c|c|c|c|c|}
\hline \multirow[b]{2}{*}{ Ingre dient } & \multicolumn{4}{|c|}{ Concentration in several varieties } \\
\hline & Cucurbita pepo L. & $\begin{array}{c}\text { Cucurbita pepo } \\
\text { Subsp. pepo Var. } \\
\left.\text { Styriaka }^{* *}\right)\end{array}$ & $\underset{* * *)}{\text { Cucurbita maxima }}$ & $\begin{array}{l}\text { Cucurbita maxima, } \\
\left.\text { var. Berrettina }^{* * * *}\right)\end{array}$ \\
\hline Palmitic acid & $9.5-14.5 \%$ & $10.86 \%$ & $15.97 \%$ & Unquantified \\
\hline Stearic acid & $3.1-7.4 \%$ & $8.67 \%$ & Unquantified & Unquantified \\
\hline Oleic acid & $21.0-46.9 \%$ & $38.42 \%$ & $44.11 \%$ & $41.40 \%$ \\
\hline Linoleic acid & $35.6-60.8 \%$ & $39.84 \%$ & $34.77 \%$ & $37.00 \%$ \\
\hline Other fatty acids & $<0.5 \%$ & Unquantified & Unquantified & Unquantified \\
\hline$\alpha$-tocopherols & n.d-91 mg/Kg & $88265 \mathrm{mg} / \mathrm{Kg}$ & $42.27 \%$ & Unquantified \\
\hline$\gamma$-tocopherols & $41-620 \mathrm{mg} / \mathrm{Kg}$ & & & Unquantified \\
\hline Daidzein & $5.6-15.3 \mathrm{ng} / \mathrm{g}$ & Identified as & Identified as & Unquantified \\
\hline Genistein & $5.6-15.3 \mathrm{ng} / \mathrm{g}$ & polyphenol: 66.27 & polyphenol: 79.6 & Unquantified \\
\hline Secoisolariciresinol & $210 \mu \mathrm{g} / \mathrm{g}$ & $\mathrm{mg} / \mathrm{Kg}$ & $\mathrm{mg} / \mathrm{Kg}^{-}$ & Unquantified \\
\hline Phytosterol & $1.6-1.9 \%$ & $1.86 \%$ & $39.60 \%$ & $63.20 \%$ \\
\hline Protein & $25.2-37 \%$ & $25.40 \%$ & $33.92 \%$ & $1.28 \%$ \\
\hline Carotenoid & Unquantified & Unquantified & Unquantified & $2.5 \mathrm{mg} / \mathrm{L}$ \\
\hline
\end{tabular}

*) Murkovic, et al., 1996; Murkovic, et al., 2004; Phillips, et al., 2005; Applequist, et al., 2006; Glew, et al., 2006; Sabudak, 2007; Ryan, et al., 2007; Stevenson, et al., 2007

${ }^{* *}$ ) Ardabili, et al., 2011

***) Rezig, et al., 2012

$\left.{ }^{* * * *}\right)$ Montesano, et al., 2018

\section{GENERAL HEALTH BENEFITS DERIVED FROM PUMPKIN SEEDS}

In general, pumpkin seeds are an extraordinarily rich source of nutraceutical, pharmaceutical, and cosmeceutical properties that exhibit many pharmacological effects and health benefits. In recent years, in vitro, in vivo, and pre-clinical studies have proven that pumpkin seeds oil has a wide spectrum of amazing biological activities (Table 2.). Moreover, the presence of high percentage of unsaturated fatty acids, sterols and tocopherol make it an excellent product which could prevent against some diseases (Patel, 2013). The widespread usage of pumpkin seed gains positive acceptance not only as edible oil but also nutraceutical. Not only the therapeutic uses of pumpkin seeds were explored, the safeties of pumpkin seeds against some organs were also tested using several methods. For example, Schiebel-Schlosser and Friederich (1998) found that there were no side effects of Benign Prostatic Hyperplasia $(\mathrm{BPH})$ patients under the treatment of capsules containing $500 \mathrm{mg}$ of a pumpkin seed 
Table 2. Some biological activities of pumpkin seeds.

\begin{tabular}{|c|c|}
\hline Activity & References \\
\hline Therapy for arthritis & Fahim, et al., 1995 \\
\hline Antitumor effect & Thompson, et al., 1996 \\
\hline Therapy for irritable bladder & Leung and Foster, 1996 \\
\hline Retarded the progression of hypertension & Al-Zuhair, Abdel-Fattah, and Abdel Latif, 1997 \\
\hline Reduced hypercholesterolemia & Makni, et al ., 2008 \\
\hline Free radical scavengers in the heart and kidney & - \\
\hline Therapy for colon cancer & Awad, von Holtz, Cone, Fink, and Chen, 1998 \\
\hline $\begin{array}{l}\text { Possessed estrogenic, antiestrogenic, antioxidative, } \\
\text { antiviral, antibacterial, insecticidal or fungistatic }\end{array}$ & Mazur and Adlercreutz, 1998 \\
\hline Reduced serum cholesterol & Jones, et al ., 2000 \\
\hline Treatment of heterophyiasis & Mahmoud, et al ., 2002 \\
\hline Immunoregulatory potential & Winkler, et al., 2005 \\
\hline Antiperoxidative properties & Nkosi, et al. , 2006 \\
\hline $\begin{array}{l}\text { Alleviated diabetes, reliefed of abdominal cramps, } \\
\text { and distension due to intestinal worms }\end{array}$ & Caili, et al. , 2006 \\
\hline Therapy for bladderstone disease & Caili, Huan, and Quanhong, 2006 \\
\hline Antioxidant and anti-inflammatory & Kühn, Chaitidis, Roffeis, and Walther, 2007 \\
\hline Therapy for benign prostate hyperplasia & $\begin{array}{l}\text { Friederich, et al ., 2000; Gossell-Williams, et al ., } \\
\text { 2006; Fruhwirth and Hermetter, 2007; Hong, et } \\
\text { al. , 2009; Jiang, et al ., 2012; Medjakovic, et al., } \\
2016\end{array}$ \\
\hline $\begin{array}{l}\text { Prevented changes in plasma lipids and blood } \\
\text { pressure }\end{array}$ & Gossell-Williams, et al ., 2008 \\
\hline Radical Scavenger and inhibit lipoxygenase & Xanthopoulou, et al ., 2009 \\
\hline Preventing diabetic complications & Makni, et al ., 2010 \\
\hline Increased of reproductive potential & Abd El-Ghany, et al ., 2010 \\
\hline Breast cancer prevention and/or treatment & Richter, et al ., 2014 \\
\hline Antigenotoxic & Elfiky, et al ., 2012; Yasir, et al ., 2016 \\
\hline
\end{tabular}

extract. Those research findings have accumulated in the recent years that endorse the wide range of therapeutic values of pumpkin seeds. More clinical trials are required to optimally utilize the nutritional potential of pumpkin seeds.

\section{ESTROGENIC-LIKE EFFECTS}

As we know that estrogen hormones play a key role in the menstrual cycle, reproduction, modulation of bone density, and cholesterol transport in the body (Rosano, et al., 2007). 
Phytoestrogen is a polyphenol compound from plant that exerts mammalian estrogenic-like effect due to the binding ability with estrogen receptor. The oil of pumpkin seeds has proved to contain high percentage of phytoestrogens and sterols such as secoisolariciresinol and lariciresinol (Patel, et al., 2012). Sicilia, et al. (2003) reported that pumpkin seeds contain secoisolariciresinol approximately 21 $\mathrm{mg} / 100 \mathrm{~g}$ of dry weight and Philips, et al. (2005) found $265 \mathrm{mg}$ of phytoestrogens/100 $\mathrm{g}$ of seeds. Supplementation of pumpkin seeds to rats showed anti-atherogenic and hepato-protective effect in hypercholesterolemic rats (Mazur and Adlercreutz, 1998; Makni, et al., 2008). Further study revealed that pumpkin seeds exhibited estrogenic-like effects such as regulating lipid metabolism, bone remodeling, mammary gland and uterus epithelial cells development. Phytoestrogen components were the key role in inhibiting cardiovascular outcomes and balancing the plasma lipids level such as total cholesterol, low-density lipoprotein (LDL), highdensity lipoprotein (HDL), and triglyceride (GossellWilliams, et al., 2008; Jones, et al., 2000; Zeb and Ahmad, 2017). In conclusion, phytoestrogens and tocopherols presented in pumpkin seeds contribute to their estrogenic-like effects.

\section{ANTICANCER ACTIVITIES}

The previous studies reported that phytoestrogen compounds in pumpkin seeds also exerted an anticancer effect. Some reports showed that pumpkin seeds are a good candidate for cancer prevention and/or cancer treatment. As described in the previous sentences, phytoestrogen compounds are related to estrogen hormones. Thus, several studies explored the association of the effect on estrogen hormone-dependent malignancies, mainly breast cancer. Richter, et al., (2013) conducted research about the anticancer effect of pumpkin seeds extract using human breast cancer cells (MCF7), human chorionic carcinoma cell lines (Jeg3 and BeWo), the results showed a cytotoxic effect on those cancer cells and elevated the estradiol production in a concentration-dependent manner. Interestingly, this phenomenon looks to be a contradiction because usually estrogenic-like effect promotes cell proliferation. One of the explanations for this phenomenon is that pumpkin seeds exert a biphasic effect, estrogenic and antiestrogenic activities through different pathways. This phenomenon also found in several phytoestrogen compounds such as genistein and daidzein (Guo, et al., 2004). Another in vitro result was reported by Medjakovic, et al. (2016), they found that hydroalcoholic pumpkin seed extract inhibited not only cancer cells proliferation but also hyperplastic cells, while weaker effects on non-hyperplastic cells. They concluded that the anticancer effect of pumpkin seeds was not mediated through sex steroid hormone receptors. The previous research also claimed that phytoestrogen like isoflavones are considered to exert estrogenic-like effects but possess nonhormonal properties that also may contribute to their effects (Messina and Loprinzi, 2001). Cytotoxic effect of pumpkin seeds ethanolic and aqueous extracts in prostate cancer in vitro was conducted by Rathinavelu, et al. (2013) and confirmed that the cytotoxic effects of both extracts of pumpkin seeds was mediated through oxidative stress, mitochondrial depolarization and apoptosis mechanisms.

Jiang, et al. (2012) reported that there was an inhibition of prostate cancer in vitro and in vivo experiments in the group treated by pumpkin seeds as a dietary supplement. The animal study using Sprague dawley rats showed that the oil from pumpkin seeds inhibited testosterone-induced hyperplasia that would be useful in the management of benign prostatic hyperplasia (Gossell-William, et al., 2006). The clinical trial of benign prostate cancer (BPH) patients has proved that after 3-months treatment with pumpkin seed oil, the symptoms were reduced especially in the early stage of cancer (Friederich, et al., 2000; Hong, et al., 2009). In the same study of human trial, a whole extract of Stryrian oil pumpkin seeds was correlated to reduce 
benign prostate hyperplasia-related symptoms (Fruhwirth and Hermetter, 2007). Many reports also claimed that the components such as cucurbitacins and moschatin were found in pumpkin seeds and in charge for anticancer activities. Cucurbitacins have been isolated from several species of pumpkin seeds and have been reported to induce apoptosis through JAK/STAT, PARP, MAPK pathways (Rios, et al., 2012). Moreover, Xia, et al. (2003) reported that moschatin from the mature seeds of pumpkin (Curcurbita moschata) inhibited the growth of targeted melanoma cells M21. In general, the molecular mechanism of anticancer effect of pumpkin seeds should be clarified further based on particular concentrations and several types of cancer cells.

\section{ANTIOXIDANT AND FREE RADICAL SCAVENGING PROPERTIES}

Pumpkin seeds oil has been proven to contain high antioxidant vitamins like tocopherol and carotenoid by several studies along with sufficient oxidative stability (Xanthopoulou, et al., 2009; Seif, 2014; Hernández-Santos, et al., 2016). In vivo experiment was conducted by Bardaa, et al., (2016) using the cutaneous wound healing rats and revealed that oil from pumpkin seeds extracted by cold pressure was better in macroscopic, morphometric and histological data of rat skin than the untreated group. The potent antioxidant effect and protective activity against genotoxic chemicals of pumpkin seeds has performed by Elfiky, et al., (2012). Those findings have been consistently and strongly demonstrated that pumpkin seeds oil was accepted as antioxidant and free radical scavenger. Fahim, et al. (1995) observed that treatment with pumpkin seeds oil decreased free radicals and was helpful for arthritis. In addition, Yasir, et al. (2016) reported that extract of pumpkin seeds exhibited antioxidant and genoprotective effects. Overall, the high amount of tocopherol present in the pumpkin seeds might be considered as playing a protective role against toxic substances and free radicals.

\section{NUTRACEUTICAL POTENTIAL AND FUTURE PROSPECTIVE}

In the recent years, pumpkin seeds have a large range of application as a food or herbal medicine. Those waste streams are valuable and can be utilized for food products and/or nutraceutical products. They can be consumed as a snack, salads or breakfast cereal in the roasted form (salted or not). In addition, they could be used in baking as the excellent ingredients of bread or cakes. Moreover, their oil is excellent and could gain acceptance as edible oil and additive component in food, pharmaceutical and cosmetic industries. Pumpkin seeds oil is useful for frying, cooking, baking and salad dressing. Supplement from pumpkin seeds could be developed in the form of a soft capsule. In cosmetic industries, they usually use for skin care products such as antiaging, free-radical scavenging, skin protection and hair care products such as hair growth stimulants and emollients. The consumption of pumpkin seeds in the oil form or roasted pumpkin seeds is proved to exhibit several positive health effects.

\section{CONCLUSION}

The general conclusion of this literature study is that pumpkin seeds have emerging bioactive compositions that promote health and human life. All of these findings bring us to the new idea in developing and innovating nutraceuticals, pharmaceuticals, and cosmeceuticals products from pumpkin seeds for the large range application.

\section{REFERENCES}

Abd El-Ghany, M., Dalia, A.H. and Soha, M., 2010, Biological Study on The Effect of Pumpkin Seeds and Zinc on Reproductive Potential of Male Rats. In: The 5th Arab and 2nd International Annual Scientific Conference on Recent Trends of Developing Institutional and Academic Performance in Higher Specific Education Institutions in Egypt and Arab World, pp.23842404. 
Indonesian Journal of Cancer Chemoprevention, June 2018 ISSN: 2088-0197

e-ISSN: $2355-8989$

Applequist, W. L., Avula, B., Schaneberg, B. T., Wang, Y.H. and Khan, I. A., 2006, Comparative Fatty Acid Content of Seeds of Four Cucurbita Species Grown in A Common (Shared) Garden, J. Food Compost. Anal., 19, 606-611.

Al-Zuhair, H., Abdel-Fattah, A. A. and Abd el Latif, H. A., 1997, Efficacy of Simvastatin and Pumpkinseed Oil in The Management of Dietary-induced Hypercholesterolemia, Pharmacol.Res., 35(5), 403-408.

Ardabili, A.G., Farhoosh, R. and Haddad Khodaparast, M.H., 2011, Chemical Composition and Physicochemical Properties of Pumpkin Seeds (Cucurbita pepo Subsp. Pepo Var. Styriaka) Grown in Iran, J. Agr. Sci. Tech., 13, 1053-63.

Awad, A. B., von Holtz, R. L., Cone, J. P., Fink, C. S. and Chen, Y.C., 1998, b-sitosterol Inhibits The Growth of HT-29 Human Colon Cancer Cells by Activating The Sphingomyelin Cycle, Anticancer Res., 18, 471-479.

Bardaa, S., Ben Halima, N., Aloui, F., Mansour, R.B., Jabeur, H., Bouaziz, M., et al., 2016, Oil from Pumpkin (Cucurbita pepo L.) Seeds: Evaluation of Its Functional Properties on Wound Healing in Rats, Lipids Health Dis., 15(1), 73. doi: 10.1186/s12944-016-0237-0.

Caili, F., Huan, S. and Quanhong, L., 2006, A Review on Pharmacological Activities and Utilization Technologies of Pumpkin, Plant Foods Hum. Nutr., 61(2), 73-80.

Cerny, K., Korydylas, M., Pospisil, F., Svabensk, 0. and Zajiir, B., 1971, Nutritive Value of The Winged Bean (Psophocarpus palustris Desv.), Br. J. Nutr., 26(2), 293-299.

Elfiky S.A., Elelaimy I.A., Hassan A.M., Ibrahim H.M. and Elsayad R.I., 2012, Protective Effect of Pumpkin Seed Oil Against Genotoxicity Induced by Azathioprine, J. Basic Appl. Zool., 65(5), 289-98.

Fahim, A. T., Abdel-Fattah, A. A., Agha, A. M. and Gad, M. Z., 1995, Effect of Pumpkin Seed Oil on The Level of Free Radical Scavengers Induced During Adjuvant-arthritis in Rats, Pharmacol. Res., 31(1), 73-79.

Friederich, C., Theurer, G. and Schiebel-Schlosser, G., 2000, Prosta Fink Forte Capsules in The
Treatment of Benign Prostatic Hyperplasia. Multicentric Surveillance Study in 2245 Patients, Forsch. Komplementarmed. Klass. Naturheilkd., 7(4), 200-204.

Fruhwirth, G. O. and Hermetter, A., 2007, Seeds and Oil of The Styrian Oil Pumpkin: Components and Biological Activities, Eur. J. Lipid Sci.Technol., 109(11), 1128-1140.

Fu C.L., Shi H. and Li Q.H., 2006, A Review on Pharmacological Activities and Utilization Technologies of Pumpkin, Plant Foods Hum. Nutr., 61(2), 73-80.

Gemrot, F., Barouh, N., Vieu, J. P., Pioch, D. and Montet, D., 2006, Effect of Roasting on Tocopherols of Gourd Seeds (Cucurbita pepo), Gras. Aceit., 57, 409-414.

Glew, R.H., Glew, R.S., Chuang, L.T., Huang, Y.S., Millson, M., Constans, D., et al., 2006, Amino Acid, Mineral and Fatty Acid Content of Pumpkin Seeds (Cucurbita sp) and Cyperus Esculentus Nuts in the Republic of Niger, Plant Foods Hum. Nutr. , 61(2), 51-56.

Gossell-Williams, M., Davis, A. and O'Connor, N., 2006, Inhibition of Testosterone-induced Hyperplasia of The Prostate of Sprague-dawley Rats by Pumpkin Seed Oil, J. Med. Food, 9(2), 284-286.

Gossell-Williams, M., Lyttle, K., Clarke, T., Gardner, M. and Simon, O., 2008, Supplementation with Pumpkin Seed Oil Improves Plasma Lipid Profile and Cardiovascular Outcomes of Female Nonovariectomized and Ovariectomized SpragueDawley Rats, Phytother. Res., 22(7), 873-877.

Guo, J.M., Xiao, B.X., Liu, D.H., Grant, M., Zhang, S., Lai, Y.F., et al., 2004, Biphasic Effect of Daidzein on Cell Growth of Human Colon Cancer Cells, Food Chem. Toxicol., 42(10), 1641-1646.

Hernández-Santos B., Rodríguez-Miranda J., HermanLara E., Torruco-Uco J.G., Carmona-García R., Juárez-Barrientos J.M., et al., 2016, Effect of Oil Extraction Assisted by Ultrasound on The Physicochemical Properties and Fatty Acid Profile of Pumpkin Seed Oil (Cucurbita pepo), Ultrason. Sonochem., 31, 429-436.

Hong, C.S. Kim, S. Maeng, 2009, Effects of Pumpkin Seed Oil and Saw Palmetto Oil in Korean Men with Symptomatic Benign Prostatic Hyperplasia, 
Nutr. Res. Pract., 3(4), 323-327.

Jones, P.J.H., Raeini-Sarjaz, M., Ntanios, F.Y., Vanstone, C.A., Feng, J.Y. and Parsons W.E., 2000, Modulation of Plasma Lipid Levels and Cholesterol Kinetics by Phytosterol versus Phytostanol Esters, J. Lipid Res., 41, 697-705.

Kühn, H., Chaitidis, P., Roffeis, J. and Walther, M., 2007, Arachidonic Acid Metabolites in The Cardiovascular System: The Role of Lipoxygenase Isoforms in Atherogenesis with Particular Emphasis on Vascular Remodeling, J. Cardiovasc. Pharmacol., 50, 609-620.

Leung and Foster, 1996, Encyclopedia of Common Natural Ingreadients Used in Food, Drugs and Cosmetics, 2nd edition, New York: John Wiley \& Sons, Inc.

Mahmoud, L.H., Basiouny, S.O. and Dawoud, H.A., 2002, Treatment of Experimental Heterophyiasis with Two Plant Extracts, Areca Nut and Pumpkin Seed, J. Egypt. Soc. Parasitol., 32(2), 501-506. Makni M., Fetoui H., Gargouri N. K., Garoui E. M. and Zeghal N., 2011, Antidiabetic Effect of Flax and Pumpkin Seed Mixture Powder: Effect on Hyperlipidemia and Antioxidant Status in Alloxan Diabetic Rats, J. Diabetes Complicat., 25(5), 339-345.

Makni, M., Fetoui, H., Gargouri, N.K., Garoui, E.L.M., Jaber, H., Makni, J., et al., 2010, Hypolipidemic and Hepatoprotective Seeds Mixture Diet Rich in w-3 and w-6 Fatty Acids, Food Chem. Toxicol., 48(8-9), 2239-2246.

Mazur, W. and Adlercreutz, H., 1998, Naturally Occurring Oestrogens in Food, Pure Appl. Chem., 70(9), 1759-1776.

Messina, M.J. and Loprinzi, C.L., 2001, Soy for Breast Cancer Survivors: A Critical Review of The Literature, J. Nutr., 131(11), 3095S-3108S.

Miura, Y., 2013, The Biological Significance of w-oxidation of Fatty Acids, Proc. Jpn. Acad. Ser. B Phys. Biol. Sci., 89(8), 370-382.

Montesano, D., Blasi, F., Simonetti, M. S., Santini, A. and Cossignani, L., 2018, Chemical and Nutritional Characterization of Seed Oil from Cucurbita maxima L. (var. Berrettina) Pumpkin, Foods, 7(3), 30. doi: 10.3390/foods7030030.

Murkovic, M., Hillebrand, A., Winkler, J., Leitner, E., and Pfann-hauser, W., 1996, Variability of Fatty Acid Content in Pumkin Seeds (Cucurbita pepo L), Z. Lebensm. Unters. Forsch., 202(4), 275278.

Murkovic, M., Piironen, V., Lampi, A., Kraushofer, T., and Gerhard, S., 2004, Changes in Chemical Composition of Pumpkin Seeds During The Roasting Process for Production of Pumpkin Seed Oil (Part 1: Non-volatile Compounds), Food Chem., 84(3), 359-365.

Nkosi C.Z., Opoku A.R. and Terblanche S.E., 2005, Effect of Pumpkin Seed (Cucurbita pepo) Protein Isolate on The Activity Levels of Certain Plasma Enzymes in CCl4-Induced Liver Injury in Low- Protein Fed Rats, Phytother. Res., 19(4), 341-345.

Patel, D., Vaghasiya, J., Pancholi, S.S. and Paul, A., 2012, Terapeutic Potential of Secoisolariciresinol Diglucoside: A Plant Lignan, Int. J. Pharm. Sci. Drug Res., 4(1) 15-18.

Patel, S., 2013, Pumpkin (Cucurbita sp.) Seeds as Nutraceutic: A Review on Status Quo and Scopes, Med. J. Nutrition Metab., 6(3), 183-189.

Phillips, K. M., Ruggio, D. M. and Ashraf-Khorassani, M., 2005, Phytosterol Composition of Nuts and Seeds Commonly Consumed in The United States, J. Agric. Food Chem., 53(24), 94369445.

Rabrenovic B.B., Dimic E.B., Novakovic M.M., Tesevic V.V. and Basic Z.N., 2014, The Most Important Bioactive Components of Cold Pressed Oil from Different Pumpkin (Cucurbita pepo L.) seeds, Food Sci. Technol., 55, 521-7.

Rezig, L., Chouaibi, M., Msaada, K. and Hamdi, S., 2012, Chemical Composition and Pro le Characterization of Pumpkin (Cucurbita maxima) seed oil, Ind. Crops Prod., 37, 82-87.

Rosano G, Vitale C, Marazzi G, Volterrani M., 2007, Menopause and Cardiovascular Disease: The Evidence, Climacteric., 10(Suppl 1), 19-24.

Ryan, E., Galvin, K., O'Connor, T. P., Maguire, A.R. and O'Brien, N.M., 2007, Phytosterol, Squalene, Tocopherol Content and Fatty Acid Profile of Selected Seeds, Grains, and Legumes, Plant Foods Hum. Nutr., 62(3), 85-91.

Sabudak, T., 2007, Fatty Acid Composition of Seed and 
Leaf Oils of Pumpkin, Walnut, Almond, Maize, Sunflower and Melon, Chem. Nat. Compd., 43(4), 465-467.

Sanders, T.H., 1980, Effects of Variety and Maturity on Lipid Class Composition of Peanut Oil, J. Am. Oil Chem.' Soc, 1980, 57. doi: 10.1007/ BF02675516.

Seif, HS., 2014, Ameliorative Effect of Pumpkin Oil (Cucurbita pepo L.) Against Alcohol-induced Hepatotoxicity and Oxidative Stress in Albino Rats, Beni-Suef Univ. J. Basic Appl. Sci., 3(3), 178-85.

Sicilia, T., Niemeyer, H.B., Honig, D.M. and Metzler, M., 2003, Identification and Stereochemical Characterization of Lignans in Flaxseed and Pumpkin Seeds, J. Agric. Food Chem., 51(5), 1181-1188.

Stevenson, D.G., Eller, F.J., Wang, L., Jane, J.L., Wang, T. and Inglett, G.E, 2007, Oil and Tocopherol Content and Composition of Pumpkin Seed Oil in 12 Cultivars, J. Agric. Food Chem., 55(10), 4005-4013.

Thompson, L.U., Seidl, M.M., Rickard, S.E., Orcheson, L.J. and Fong, H.H.S., 1996, Antitumorigenic Effect of a Mammalian Lignan Precursor from Flaxseed, Nutr. Cancer, 26(2), 159-165.
Tindall H.D., 1983, Vegetables in the Crops, London: Macmillan Press.

Winkler J., 2000, The Origin and Breeding of Hull-less Seeded Styrian Oil-pumpkin Varieties in Austria, Cucurbit Genetics Coop. Rpt., 23, 101-104.

Xanthopoulou, M.N., Nomikos, T., Fragopoulou, E. and Antonopoulou, S., 2009, Antioxidant and Lipoxygenase Inhibitory Activities of Pumpkin Seed Extracts, Food Res. Int., 42(5-6), 641-646.

Xia, H.C., Feng, L.I., Zhen, L.I. and Zhang, Z.C., 2003, Purification and Characterization of Moschatin, A Novel Type I Ribosome-inactivating Protein from The Mature Seeds of Pumpkin (Cucurbita moschata), and Preparation of Its Immunotoxin Against Human Melanoma Cells, Cell Res., 13(5), 369-374.

Yasir M., Sultana B., Nigam P.S. and Owusu-Apenten R., 2016, Antioxidant and Genoprotective Activity of Selected Cucurbitaceae Seed Extracts and LC-ESIMS/MS Identification of Phenolic Components, Food Chem., 199, 307-313.

Zeb, A. and Ahmad, S., 2017, Changes inAcylglycerols Composition, Quality Characteristics and In vivo Effects of Dietary Pumpkin Seed Oil upon Thermal Oxidation, Front. Chem., 5, 55. doi: 10.3389/fchem.2017.00055. 